\title{
Improving Students' Scientific Literacy Through Science Learning with Socio Scientific Issues (SSI)
}

\author{
Anna Permanasari* \\ Science Education, School of Postgraduate Studies \\ Universitas Pendidikan Indonesia \\ Bandung, Indonesia \\ *anna.permanasari@upi.edu
}

Anita Sariningrum

Science Education, School of Postgraduate Studies

Universitas Pakuan

Bogor, Indonesia

anita@unpak.ac.id d

\author{
Bibin Rubini \\ Science Education, School of Postgraduate Studies \\ Universitas Pakuan \\ Bogor, Indonesia \\ bibinrubini@unpak.ac.id \\ Didit Ardianto \\ Science Education, School of Postgraduate Studies \\ Universitas Pakuan \\ Bogor, Indonesia \\ ardianto@unpak.ac.id
}

\begin{abstract}
This study aims to investigate the effect of Socio Scientific Issues (SSI) approach in the science learning to enhance students' scientific literacy. 90 students of 8th graders, who were divided into three classes, were involved. They learned by using the same SSI approach but with the different themes, including global warming, food additives, and living thingenvironment interaction. After the learning process, students performed the literacy test related to the topics. The results showed that the SSI approach in science learning made students feel the need to learn science, and makes learning more meaningful. In addition, the students' scientific literacy increased in the high category after the implementation. All three aspects of competency, including explaining scientific phenomena, interpreting data and scientific evidence, and evaluating data and facts scientifically, showed a high increase. The similar increase was also shown in knowledge aspects. On the other hand, the enhancement of attitude toward science aspect showed lower category in average.
\end{abstract}

Keywords-scientific literacy, socio scientific issues, science learning

\section{INTRODUCTION}

Scientific literacy is an individual skill to solve the problems related to science in daily life. Scientific literacy leads ones to develop and to deepen knowledge and understand to the scientific concepts as well as to the process which is needed make a personal decision, to participate in social, cultural, and economy productivity. The application should be done not only in college but also throughout the long life.

Indonesia is now still facing on the reality the lower achievement of scientific literacy, in most of student. The low achievement of literacy is caused by many factors, one of them is the low of science teachers understanding on scientific literacy itself. Based on the observation of some science teachers shows that they still did not fully understand too the scientific literacy concepts. As the impact, they feel confuse in how to plan the learning, how to arrange and how to make the assessment for scientific literacy. Indonesia government in systematic and sustainable manner has planned and conducted some effort to make sure that all of science teachers understand and can be able to practice the learning to the student. The Indonesia of the ministry of education has launched the score of scientific literacy of student on year 2025 is 500 (based in PISA score). The PISA score for scientific literacy of Indonesia student at 2028 is 396 in average. This target sounds very ambitious, but Indonesia has no other choice. This must be done, so that Indonesian students are not left behind student from other countries.

In order to achieve the target, various methods and involvement of many parties are required. Government through the Ministry of Education and Culture and Non-government Organization (NGO) such as Science Educators Association has been several years on the move. The development research on science learning based on scientific literacy has already carried out by researchers from both of University and other institutions. The results have been applied to science teacher training activities.

Some researches on enhancing scientific literacy are still relevant to be carried out. The research focus on the models, approach, and strategies of learning science as well as in scientific literacy-based assessments. Some results have been done to make sure the enhancement of scientific literacy of student through the implementation of innovation learning on using models and approach those have characteristics can building students' thinking skills. Thinking skills is the basic modals to develop scientific literacy. One of the learning 
sciences which is very popular is problem-based learning. Problem based learning with the socio scientific contexts has been widely researched for its effectivity and efficiency to enhance scientific literacy of student [1-7].

Socioscientific issues (SSI) has a highly contextuality aspect, presenting a dilema or even problematic problem. These problems can be solved by using science knowledge and social awareness that arise in mental conflict. People who have scientific literacy will be able to solve problems and make responsible decisions [8,9]. SSI contains crucial issues related to science, conceptually, procedurally, as well as epistemically. Besides, SSI orientates the learning in the context of science and its relationship with social life by using issues that exist in society [8-12]. Students are faced with conflict situations that exist in their life. Thus, this approach will have an impact on building a sense of responsibility as well as values and morals behavior of student.

Based on the description above, it can be concluded that learning with SSI packaged in controversial and debatable society problems is very relevant with science learning. The context raised must make students engage in exiting debates. The debate skills are very close related to the argumentation skills of students. The argumentation skills are the embryo of the critical thinking skills. Besides, the issues raised is in general resulting the multi solutions, so it will lead to the habit of student being problem solvers. Because of the learning is based on scientific literacy, learning will automatically build moral responsibility. Moral responsibility will be the basic modality in building education for sustainability development (ESD).

The issues related to global warming, food additives, and living things interaction, are the three themes that has so many issues in society. The three themes are taught in science leaning at junior secondary school. Based on PISA framework 2015, the global warming theme is relevant to the context danger, and relate to the climate change and impact of globalization. Food additive theme are in category of disease control, food technology, public health in the context of health and disease. Meanwhile, living things interaction includes the category of pollution prevention, maintenance the biological diversity from the context of environmental preservation. It is very interesting to research how the SSI based learning contributes to enhance the scientific literacy of student.

Based on the description above, we have done the research on planning and implementing the learning science based on SSI. The research questions were: (1) How were the attitude of student toward the learning after SSI learning? (2) how were the enhancing of scientific literacy of student includes: knowledge, competence as well as attitude toward science, after the learning?

\section{Methods}

The research was done on using quasi experimental methods with pre-posttest control group design [13]. Three classes were used as experimental class, meanwhile the other three classes were used as a control class. Each of class consist of 30 students, in both of experimental and control classes (totally the research involved 180 student of junior secondary school). The three experimental classes were treated with the SSI learning on using the different theme: global warming (class A or GW), food additives the second class (Class B/FA), and living things interaction theme for the third class (class C/LI). Meanwhile, the three control classes were treated with the inquiry-based learning on using the same topics/themes.

In the experimental class, the learning was initialized with the video about the issue/context aroused that time. Those are (1) the phenomena of ice melting event of the north pole and has an impact on increasing the sea water level of several, (2) regarding the abuse of textile dyes in the manufacture of children's food/snacks, and (3) how forest burning occurs deliberately by irresponsible people. Afterwards, the students gave comment and then leads to the formulation of main problems based on the case. They can solve the problem after find the other information needed. They were also directed to the group discussion, and then did some simple experiments if it is needed. Teacher were also involved to make sure that the concept gain is on the track. At the end of session, students were asked to communicate their investigation research. In this session, teachers made some strengthening of the acquisition of concepts of student and the way of students think in finding concepts.

At the end of learning, students were asked to fill the questioner about what they feel along the learning and what they have got from the learning. Students were also done the scientific literacy test for knowledge, competencies (skills) and attitude toward science aspects. The instrument test was in multiple choice term for all of aspects/domains. The indicators included in competency domain were explaining scientific phenomena, interpreting data and scientific evidence, and Evaluating data and facts scientifically. The science knowledge measured were Factual, Conceptual, Epistemic indicators. Meanwhile, the indicators for attitude toward science included Interest in science, Assess the scientific approach to inquiry, and Environmental awareness. Besides, research team was also proposed the one essay measurement for strengthening the data came from the multiple-choice test, especially for competence domain.

After gaining the data, the analysis data was conducted and was processed on using two ways, descriptive and quantitative analysis. The quantitative analysis was treated for the multiplechoice test, meanwhile the descriptive analysis was used for the data come from questioner and essay test.

The quantitative data analysis was done on using simple statistics (N-gain) for totally score of literacy and for every domain of literacy. Data from every domain (competence and attitude toward science) were then elaborated into the indicators score. For competence domain, the analysis result was then confirmed by the tendency of students 'answers to the essay test results. 


\section{RESUltS AND DISCUSSION}

Overall, the learning situation in every class (in both of control and experimental classes) were well control and very conducive. All steps of learning were in line with the learning plan and stages. In the experimental classes, phase 1 was begun with giving students an orientation to problem. At this stage, student watched the video with the specific theme that they will learn. The students seemed to be active with the learning and seriously followed the video storyline. Student were also seen commenting the video with the various comments.

In the phase 2, teacher gave the direction to students to research why is this happened? what are the factors cause? and what should they do? Students were in group and then plan the action. They divided the task to find sources of information related to science behind the issues that arise.

In the phase 3 , student did the investigation with their group to find the answer. In this phase, student learned the science concepts behind the issue to find the answer or to get the appropriate explanation. Developing and presenting the investigation is the activity on the phase 4. Students in the group preparing the report and make the power point presentation. Students were also directed to make a video along the investigation.

In the last phase (phase 5), students in group presented the research report. The other groups should give some comments, reflections and suggestions. Teacher was also given some comments and reward. At the end of session, teacher reinforced both concepts and thinking skills as well as encouraged students to be responsible and behave when they are finding the such situation in the society, for example minimizing waste, ensuring that our families do not use hazardous additives in food, and minimizing activities that goes to the potential to accelerate global warming.

All of student stated that learning on using SSI make they were enjoying the session, so it will lead to the better understand toward science (Table 1). Moreover, most of student would tell their learning experience to their parent. Some students answered no to this statement. They thought that their parent would not care what they have done at school, they are too busy. One student and two students in class FA and LI (B and C) said that they didn't interest to learn science because they want to be a lawyer, economist, and others. The same students also stated that learning science is just for all people who want to learn science.

TABLE I. STUdENTS' RESPONSE TOWARD SCIENCE LEARNING WITH SSI

\begin{tabular}{|l|l|c|c|c|}
\hline No & \multicolumn{1}{|c|}{ Statement } & GW & FA & LI \\
\hline 1 & I Enjoy learning using SSI & $100 \%$ & $100 \%$ & $100 \%$ \\
\hline 2 & $\begin{array}{l}\text { Learning science with SSI make } \\
\text { better understand to concept }\end{array}$ & $100 \%$ & $100 \%$ & $100 \%$ \\
\hline 3 & $\begin{array}{l}\text { I will tell the learning experience to } \\
\text { my parent }\end{array}$ & $83 \%$ & $80 \%$ & $80 \%$ \\
\hline 4 & $\begin{array}{l}\text { I always willing to learn science } \\
\text { Learning science is important to all } \\
\text { of people }\end{array}$ & $100 \%$ & $93 \%$ & $97 \%$ \\
\hline 5 & $93 \%$ & $97 \%$ \\
\hline
\end{tabular}

GW: Global warming; FA: Food additives; LI Living things Interaction

The result from test resulted slightly different with the questioner data, as it is shown by table 2. Even the enhancement on interest to science shows not good, but actually the pre test of the point has already high achievement, so the enhancement is only in fair category.

TABLE II. THE ENHANCEMENT OF STUDENTS' SCIENTIFIC LITERACY IN ALL OF THREE EXPERIMENTAL CLASSES

\begin{tabular}{|c|c|c|c|c|c|}
\hline \multirow[t]{2}{*}{ SL Domain } & \multirow[t]{2}{*}{ Indicators } & \multicolumn{3}{|c|}{$\begin{array}{c}\text { Enhancement } \\
(\%)\end{array}$} & \multirow[t]{2}{*}{$\begin{array}{l}\text { Category } \\
\text { Average }\end{array}$} \\
\hline & & $G W$ & $F A$ & $L I$ & \\
\hline \multirow{3}{*}{ Competencies } & $\begin{array}{l}\text { explaining } \\
\text { scientific } \\
\text { phenomena }\end{array}$ & 78 & 80 & 78 & High \\
\hline & $\begin{array}{l}\text { interpreting } \\
\text { data and } \\
\text { scientific } \\
\text { evidence }\end{array}$ & & 50 & 55 & Fair \\
\hline & $\begin{array}{l}\text { Evaluating data } \\
\text { and facts } \\
\text { scientifically }\end{array}$ & 52 & 55 & 45 & High \\
\hline Knowledge & $\begin{array}{l}\text { Factual, } \\
\text { Conceptual, } \\
\text { Epistemic }\end{array}$ & 56 & 61 & 58 & High \\
\hline \multirow{3}{*}{$\begin{array}{l}\text { Attitude } \\
\text { Toward } \\
\text { Science }\end{array}$} & $\begin{array}{l}\text { Interest in } \\
\text { science }\end{array}$ & 47 & 40 & 42 & Fair \\
\hline & $\begin{array}{ll}\text { Assess } & \text { the } \\
\text { scientific } & \\
\text { approach } & \text { to } \\
\text { inquiry } & \\
\end{array}$ & 40 & 38 & 36 & \\
\hline & $\begin{array}{l}\text { Environmental } \\
\text { awareness }\end{array}$ & 30 & 29 & 27 & \\
\hline
\end{tabular}

The pleasure to learn science has not been followed by a willingness to take action in accordance with the attitude toward science. This is shown by the low category for both of assess scientific approach to inquiry and environmental awareness. Nevertheless, there is hope to improve this positive attitude, because it does take time. As it is stated by Sadler [14], learning with SSI will leads to moral sensitivity and it will appear after several times of learning with SSI.

As it is seen at table 2, the enhancement of competence as well as knowledge of student in all classes showed high category in average. This is believed as an impact of the SSI learning. As it was stated by Capkonoglu et al. [15]. The SSI brings the real data that will leads to the increase of quality of discussion (argumentation) of student. Along the discussion, student can make the decision and formulate solutions to problems that occur in society, either in an ordinary and creatives ways. As it were stated by science education experts, that the argumentation, formulating, and decision making are indicators of scientific literacy, so it is very relevant that SSI can enhance students' scientific literacy [2,8,16-20].

Eventhough, we have to put our concern to the enhancement of interpreting data and scientific evidence this is still fair in category, especially for the class GW (A) with low 
category in average. This is inline with the student answered to the essay question (Figure 1). Generally students provide a complete explanation of question a. They said that the significant reduction in the number of trees will lead to the extinction of animal species, because their habitate and food resources are severally reduced. When they asked to relate the question a to answer the question b, some students could not give the clear explanations. Most of them only said that in the next years after, the number of tree will be much decrease. They do not think any longer, for example, will increase if we take preventive actions, such as reforestation or if government apply severe penalties for the forest destroyers.

Most of student answer correctly for question c. They answered at least three ways to improve the quality of foret as follows:

- The government must be firmed against the perpetrators of forest burning that have been happening along years.

- There must be high taxes for forest product management businesses.

- Provide outreach to the community so that they do not destroy and burn forest.

- Panting a million treess in each area of deforested forest

- Create artificial forest in unproductive areas.

- Inviting industry and society to carry out the forest preservation.

The following are data on the reduction of animal species in forests in three areas along the years.

\begin{tabular}{|l|l|l|}
\hline Island & Year 2009 & Year 2013 \\
\hline Java & 1,002 & 675 \\
\hline Bali NTB/NTT & 1,350 & 1,188 \\
\hline Maluku & 4,577 & 4,335 \\
\hline
\end{tabular}

a) Describe your opinion about the condition of primary forests in Indonesia and their role for living things.

b) Connect with data in the table, what will happen in the next years after?

c) What should be done so that conditions improve in the future?

Fig. 1. One of essay question asked during the learning process.

The student answer for question c means that the students has already got the argumentation skills. As it is said by Dawson [21-23], the SSI learning provides the argumentation skills, so in the end will build scientific literacy. In this case, students seem a little confused about what to answer, even though they can answer the question c, that should be more difficult that the first one. By the true answering question, it means that students can evaluate data and facts scientifically. The answer is in line with the data in table 2, that students got the high category for evaluate data and facts scientifically.

\section{CONCLUSION}

By the research it is clearly shown that learning science with SSI approach enhanced the meaningful learning, scientific literacy, and students' participation. The science learning on using SSI enhanced student Science literacy in all domains of literacy. The enhancement of domain knowledge and competence were high in category, meanwhile in low category for attitude toward science domain.

\section{ACKNOWLEDGMENT}

The authors are grateful to the principal of Junior High School in Bandung and Bogor cities for the participation. Many thanks also addressed to school of Postgraduate Studies of UPI and UNPAK for research grant.

\section{REFERENCES}

[1] T.D. Sadler, D.L. Zeidler and S.M. Fowler, "Moral sensitivity in the context of socioscientific issues in high school science students," International Journal of Science Education, vol. 31, no. 2, pp. 279-296, 2009 .

[2] T.D. Sadler and D.L. Zeidler, "Scientific Literaרcy, PISA, dan Socioscientific Discourse: Asess $\neg$ ment for Progressive Aims of Science Educaᄀtion," Journal of science Teaching, 1-13, 2009

[3] A. Fibonacci and Sudarmin, "Development fun-chem learning materials integrated socio-science issues to increase studentsscientific literacy," International Journal of Science and Research, vol. 11, no. 3, pp. 708$713,2014$.

[4] R. Khishfe, F.S. Alshaya, S. BouJaoude, N. Mansour, and K.I. Alrudiyan, "Students' Understandings of Nature of Science and Their Arguments in the Context of Four Socio-Scientific Issues," International Journal of Science Education, vol. 39, no. 3, pp. 299-334, 2017.

[5] R. Khishfe, "Consistency of Nature of Science Views Across Scientific and Socio-Scientific Contexts," International Journal of Science Education, vol. 39, no. 4, pp. 403-432, 2017.

[6] R. Khishfe, "Explicit Nature of Science and Argumentation Instruction in the Context of Socioscientific Issues: An effect on student learning and transfer," International Journal of Science Education, 974-1016, 2013.

[7] R. Istiana and D. Herawati, "Student Argumentation Skill Analysis of Socioscientific Issues in Solving Environmental Problems," Journal of Humanities and Social Studies, vol. 3, no. 1, pp. 22-26, 2019.

[8] J. Holbrook and M. Rannikmae, "The Meaning of Scientific Literacy," International Journal of Science Education, vol. 4, no. 3, pp. 275-288, 2009

[9] J. Holbrook and M. Rannikmae, "The Nature of Science Education for Enhancing Scientific Literacy," International Journal of Science Education, vol. 29, no. 11, pp. 1347-1362, 2007.

[10] D.L. Zeidler and B.H. Nichols, "Advancing Reflective Judgmen through Socio-scientific Issues," Journal of Research in Science Education, vol. 46, no. 1, pp. 74-101, 2009.

[11] A.W. Subiantoro, "Socio-scientific Issues and Its Potency on Biology Instruction for Character Education in Indonesia," Proceeding of The 4th International Conference on Science and Mathematics Education.Malaysia: Seameo Recsam, 2011

[12] C. Foong and E.G.S. Daniel, "Students' Argumentation Skills Across Two Socio-Scientific Issues in a Confucian Classroom: Is Transfer Possible?," International Journal of Science Education, vol. 35, no. 14 pp. 2331-2355, 2013. 
[13] J. Creswell, Riset Pendidikan: Perencanaan, Pelaksanaan, dan Evaluasi Riset Kualitatif \& Kuantitatif. Yogyakarta: Pustaka Pelajar, 2015.

[14] T.D. Sadler and D. Troy, "Moral Sensitivity and Its Con $\neg$ tribution to the Resolution of Socio-scientific Issues," Journal of Moral Education, vol. 33, no. 3, pp. 339-358.

[15] E. Capkinoglu, S. Yilmaz and G. Leblebicioglu, "Quality of Argumentation by Seventh-Graders in Local Socioscientific Issues," Journal of Research in Science Teaching, pp. 1-29, 2019

[16] S.S. Anagun and M. Ozden, "Teacher Candidates' Perceptions Regarding Socioscientific Issues and Their Competencies in Using Socioscientific issues in Science and Technology Instruction," Journal of Procedia Social and Behavioral Science, vol. 9, pp. 981-985, 2010.

[17] K. Mun, H. Lee, S. Kim, K. Choi, S. Choi and J. Krajcik, "CrossCultural Comparison of Perceptions on the Global Scientific Literacy With Australian, Chinese, and Korean Middle School Students,' International Journal of Science and Mathematics Education, vol. 13, no. 2, pp. 437-465, 2013.

[18] C. Chin, W. Yang and H. Tuan, "Argumentation in a Socioscientific Context and its Influence on Fundamental and Derived Science
Literacies," International Journal of Science and Mathematics Education, vol. 14, pp. 603-617, 2016

[19] H. Chen, H. Wang, Y. Lu, and Z. Hong, "Bridging the Gender Gap of Children's Engagement in Learning Science and Argumentation Through a Modified Argument-Driven Inquiry," International Journal of Science and Mathematics Education, vol. 17, pp. 635-655, 2019.

[20] D.L. Zeidler and H.N. Bryan, "Socioscientific Issues: Theory and Practice," Journal of Elementary Science Education, vol. 21, no. 2, pp. 49-58, 2009.

[21] V. Dawson and K. Carson, "Introducing Argumentation About Climate Change Socioscientific Issues in a Disadvantaged School," Research in Science Education, 50, 863-883, 2018.

[22] V.M. Dawson and G. Venville, "Teaching Strategies for Developing Students' Argumentation Skills About Socioscientific Issues in High School Genetics," Research in Science Education, 40, pp. 133-148, 2010

[23] J.L. Eastwood, T.D. Sadler, D.L. Zeidler, A. Lewis, L. Amiri, and S. Applebaum, "Contextualizing Nature of Science Instruction in Socioscientific Issues," International Journal of Science Education, vol. 34, no. 15, pp. 2289-2315, 2012. 